\title{
IN VITRO ANTIBACTERIAL EFFICACY OF PLECTRANTHUS AMBOINICUS MEDIATED SILVER NANOPARTICLES AGAINST URINARY TRACT PATHOGENS
}

\author{
SREELAKSHMY S, THANGAPANDIYAN S* \\ Department of Zoology, PSG College of Arts and Science, Coimbatore, Tamil Nadu, India. Email: stp.nano@gmail.com
}

Received: 23 June 2018, Revised and Accepted: 05 October 2018

\begin{abstract}
Objective: The objective of the present study is to synthesize green mediated silver nanoparticles (AgNPs) using Plectranthus amboinicus leaf extract and to evaluate its antibacterial activity against selected urinary tract infection (UTI) causing bacteria.

Methods: Phytoconstituents present in leaf extract of $P$. amboinicus (Lour.) Spreng were analyzed by standard qualitative tests. The synthesized AgNPs were characterized by visual inspection, ultraviolet-visible spectroscopy, Fourier transform infrared spectroscopy, X-ray diffraction, scanning electron microscopy, and energy dispersive spectroscopy. The antibacterial activity of synthesized AgNPs was examined against the UTI pathogens such as Pseudomonas aeruginosa, Enterobacter sp., Klebsiella pneumonia, and Escherichia coli. The minimum inhibitory concentration (MIC) and minimum bactericidal concentration (MBC) of AgNPs were carried out by broth dilution method and standard plate count method, respectively.
\end{abstract}

Results: Synthesized AgNPs exhibited a spherical shape with an average size of $17.3 \mathrm{~nm}$. The antibacterial activity of AgNPs against tested bacterial pathogens showed a maximum inhibition zone of $22.00 \pm 1.00 \mathrm{~mm}$ against $P$. aeruginosa. The bacterial growth inhibition was confirmed by MIC and $\mathrm{MBC}$.

Conclusion: P. amboinicus leaf extract mediated AgNPs could be used as an effective antibacterial agent for the management of UTIs. Surface modifications of urinary catheters with AgNPs may prevent the risk of contamination and the associated infections.

Keywords: Silver nanoparticles, X-ray diffraction, Scanning electron microscopy, Energy dispersive spectroscopy, Antibacterial activity, Minimum inhibitory concentration, Minimum bactericidal concentration.

(C) 2019 The Authors. Published by Innovare Academic Sciences Pvt Ltd. This is an open access article under the CC BY license (http://creativecommons. org/licenses/by/4. 0/) DOI: http://dx.doi.org/10.22159/ajpcr.2019.v12i2.28079

\section{INTRODUCTION}

Bacterial infections are the leading cause of death for millions of people. This is due to the emergence and increase in the number of multidrugresistant microorganisms due to the indiscriminate use of antimicrobial agents $[1,2]$. It has been estimated to affect 150 million people each year worldwide with an annual incidence of $12.6 \%$ in women and $3 \%$ in men [3]. Functioning antibiotics make urinary tract infection (UTI) only a minor annoyance but if antibiotics fail, the infection can spread into the kidneys and bloodstream and even becomes life threatening. Appropriate treatment of UTI is important for successful treatment and prevention of complications.

However, with the increasing prevalence of antibiotic-resistant urinary pathogens, the selection of an appropriate agent is more difficult. This was reflected in the 2010 clinical practice guidelines which recommended the use of nitrofurantoin as a first-line agent, in the place of cotrimoxazole, due to a rise in the occurrence of organisms resistant to the latter $[4,5]$.

The emergence of nanoscience and nanotechnology in the past decade represents opportunities for exploring the bactericidal effects of metal nanoparticles. The bactericidal effect of metal particles has been attributed to their small size and high surface to volume ratio thereby enhancing its biological and chemical activity with high antibacterial efficacy $[6,7]$. Among the noble metal nanoparticles, silver nanoparticles (AgNPs) have become the focus of intensive research due to its wide range of applications for many sectors of life and industry [8]. AgNPs are capable of killing about 650 types of pathogens, and it is also known to be efficient even in small quantities $[9,10]$.

The exploitation of different plant material for the biosynthesis of nanoparticles provides advancement over chemical and physical method as it is cost-effective, easily scaled up for large-scale synthesis, and eco-friendly [11]. Plectranthus amboinicus (Lour.) Spreng is traditionally used as an herbal drug for chronic ailments [12]. This herb is widely used by the indigenous people of tropical rainforests either in folk medicine or for culinary purposes. This is mainly due to its natural production of essential oil with high amounts of bioactive compounds such as Thymol [13], $\beta$-caryophyllene, $\alpha$-humulene, $\gamma$-terpinene, p-cymene, $\alpha$-terpineol, and $\beta$-selinene, identified in the oil component of its leaves $[14,15]$. Medicinal plants serve to be a source of remedy for many diseases and place an important role in the health of an individual and society [16].

The aim of this work was a fabrication of AgNPs mediated from $P$. amboinicus leaf extract, its characterization and testing its antibacterial activity against UTI pathogens.

\section{MATERIALS AND METHODS}

\section{Materials}

Pure and analytical grade chemicals were used in this study. Silver nitrate $\left(\mathrm{AgNO}_{3}\right)$, ethanol, nutrient agar, nutrient broth, Mueller-Hinton agar, and agar were purchased from HiMedia (P) Ltd., Mumbai, India, and were used as starting materials without further purification.

\section{Methods}

Collection and identification of plant

Healthy, disease-free and mature leaves of $P$. amboinicus (Lour.) Spreng were collected from the region of Sulur, Coimbatore district, Tamil Nadu, India. The collected plant material was identified and authenticated with the help of Botanical Survey of India, Tamil Nadu, India, Agricultural University Campus, Tamil Nadu, India. 


\section{Preparation of plant leaf extract}

About $25 \mathrm{~g}$ of freshly collected P. amboinicus (Lour.) Spreng leaves were washed thoroughly under running tap water. They were washed again with deionized water to remove dirt. The leaves were boiled in $100 \mathrm{ml}$ of deionized water at $60^{\circ} \mathrm{C}$ for about $5 \mathrm{~min}$ followed by cooling and filtering using Whatman No. 1 filter paper to obtain the plant extract [17]

\section{Green synthesis of AgNPs using P. amboinicus leaf extract}

A solution of $0.1 \mathrm{mM} \mathrm{AgNO}_{3}$ was prepared by dissolving $0.1698 \mathrm{~g}$ of $\mathrm{AgNO}_{3}$ in $1 \mathrm{~L}$ of distilled water. For the fabrication of AgNPs, $10 \mathrm{ml}$ of the plant leaf extract was added to $90 \mathrm{ml}$ of $1 \mathrm{mM} \mathrm{AgNO}_{3}$ in $250 \mathrm{ml}$ conical flask and kept over orbital shaker at $120 \mathrm{rpm}$ for $5 \mathrm{~h}$ at room temperature [16]. Formation of AgNPs was marked by the appearance of reddish brown color. The synthesized AgNPs were separated from the reaction mixture by centrifugation at $9000 \mathrm{rpm}$ for $20 \mathrm{~min}$. The particles were then washed with deionized water and were dried overnight at room temperature. The resulting powder was used for the following analysis.

\section{Characterization}

\section{Phytochemical analysis of plant leaf extract}

Phytochemical screening of the freshly prepared plant leaf extract of P. amboinicus (Lour.) Spreng was carried out by following standard procedures [18] to analyze the presence of various phytoconstituents such as carbohydrates, alkaloids, terpenoids, flavonoids, tannins, steroids, anthraquinones, saponins, resins, glycosides, and phenols.

\section{Visual inspection}

The reduction of metal ions was roughly monitored by visually observing the change of color in the reaction solution.

\section{Ultra violet (UV)-visible absorption spectroscopy}

The formation of AgNPs by the reduction of pure silver ions was noticed by measuring the UV-visible spectrum of the reaction solution in $1 \mathrm{ml}$ of its sample.

\section{Fourier transform infrared (FTIR) spectroscopy}

FTIR spectra of the plant extract and plant-mediated nanoparticles were achieved in a Shimadzu FTIR spectrophotometer by registering amplitude waves ranging from 4000 to $400 \mathrm{~cm}^{-1}$ to determine the mode of interactions between plant extract and the nanoparticle surface.

\section{$X$-Ray diffraction (XRD)}

The crystallographic analysis was performed by powder XRD. The diffraction patterns of the synthesized nanoparticles were observed according to the description of Wang [19]. The XRD pattern of nanoparticles was recorded in the scanning mode of an X'Pert PROPAN analytical instrument $(\lambda=1.54060 \AA)$. The resultant diffraction intensities were recorded from $10^{\circ}$ to $90^{\circ}$ in $2 \theta$ angles and compared with the standard JCPDS files. The average size of the nanoparticles can be estimated by the full width at half maximum (FWHM) from diffraction peaks using Debye-Scherrer's equation:

$$
\mathrm{D}=\frac{\kappa \lambda}{\beta \cos \theta}
$$

Where,

$\mathrm{D}$ is the thickness of the nanocrystal, $\mathrm{k}$ is a constant, $\lambda$ is the wavelength of X-ray, and $\beta$ is the FWHM of reflection at Bragg's angle $2 \theta$.

\section{Scanning electron microscopy (SEM)}

Morphological characteristics of the green synthesized AgNPs were obtained through SEM operated at $5 \mathrm{kV}$, magnification $100 \mathrm{kx}$.

\section{Energy dispersive spectroscopy (EDS)}

Elemental analysis of nanoparticles was carried out using EDS instrument in a resolution of $134.12 \AA$, operated at $20.0 \mathrm{kV}$ with a magnification of $5 \mathrm{k}$ to determine the elemental composition and purity of the sample.

\section{Antibacterial studies of plant leaf extract}

The antibacterial activities of plant extract of $P$. amboinicus and P. amboinicus mediated AgNPs were evaluated using disc diffusion method [20]. Pure cultures of each bacterial strain were subcultured. Each strain was swabbed uniformly onto the individual Mueller-Hinton agar plates using sterile cotton swabs. Whatman No. 1 filter paper discs of $6 \mathrm{~mm}$ diameter were impregnated with $50 \mu \mathrm{L}$ of plant extract and $50 \mu \mathrm{l}$ of freshly prepared AgNP solution which were used to evaluate the antimicrobial activity. Disc impregnated with deionized water was used as a control. The discs were placed on agar plates and incubated at $37^{\circ} \mathrm{C}$ for $24 \mathrm{~h}$. Antibacterial activities were then determined by measuring the clear zone of inhibition around the discs. The assay was performed in triplicate.

Determination of minimum inhibitory concentration (MIC) and minimum bactericidal concentration (MBC) of P. amboinicus mediated AgNPs

The MIC was determined based on liquid batch cultures according to the modified method [21]. Liquid batch cultures containing various concentrations of AgNPs in suspension (100-1000 $\mu \mathrm{g} / \mathrm{ml}$ ) were taken in sterile test tubes each containing $10 \mathrm{ml}$ nutrient broth and were mixed well for $10 \mathrm{~min}$ after adding the nanoparticles to prevent aggregation. Subsequently, the tubes were inoculated with $0.1 \mathrm{ml}$ of freshly prepared bacterial suspension and then incubated overnight at room temperature. A negative control without bacterium and a positive control without AgNPs were incubated for comparative purpose. After incubation, MIC measurements were done for each tested bacterial strain at $540 \mathrm{~nm}$ using spectrophotometer (ELICO SL 207 MINI SPEC). The MBC, that is, the lowest concentration of AgNPs that kills 99.9\% of the bacteria was also determined from the batch culture studies [22].

\section{Assessment of activity index (AI) and fold area increase}

The $\mathrm{AI}$ and the fold area increase were calculated by the mean surface area of the inhibition zone generated by the leaf extract alone and in combination with the AgNPs using the following equations:

$$
\text { Activityindex }=\frac{\mathrm{b}}{\mathrm{a}}
$$

and

$$
\text { Fold area increase }=\frac{b^{2}-a^{2}}{a^{2}}
$$

Where,

"a" is the zone of inhibition for the leaf extract and

"b" is the zone of inhibition for the AgNPs.

\section{Statistical analysis}

The results of antimicrobial activity are presented as mean \pm SD. The experimental data of antimicrobial activity of $P$. amboinicus plant leaf extract and P. amboinicus leaf extract mediated AgNPs were analyzed by ANOVA.

\section{RESULTS AND DISCUSSION}

\section{Collection and identification of plant}

The collected and identified healthy, disease free and mature leaves of P. amboinicus (Lour.) Spreng are represented in Fig. 1. 
Green synthesis of AgNPs using $P$. amboinicus leaf extract

Green synthesis of AgNPs was achieved using P. amboinicus leaf extract. Fig. 2 represents the dried powder form of AgNPs.

\section{Characterization}

Phytochemical analysis of plant leaf extract

The results of the phytochemical analyzes of the leaf extract of P. amboinicus (Lour.) Spreng are given in Table 1.

\section{Visual inspection}

The change in solution color from colorless to reddish-brown was a clear indication of the formation of green mediated AgNPs in the

Table 1: Qualitative phytochemical analysis of leaf extract of P. amboinicus

\begin{tabular}{lll}
\hline Phytoconstituents & Test adopted & Results \\
\hline Saponins & Foam test & - \\
Terpenoids & Salkowski test & + \\
Tannins & Lead acetate test & + \\
Glycosides & Keller Killiani's test & + \\
Anthraquinones & Benzene test & - \\
Flavonoids & Sodium hydroxide test & + \\
Alkaloids & Mayer's test & + \\
Phenols & Ferric chloride test & + \\
Resins & Sodium hydroxide test & - \\
Carbohydrates & Benedict's test & + \\
\hline
\end{tabular}

+: Present, -: Absent. P. amboinicus: Plectranthus amboinicus

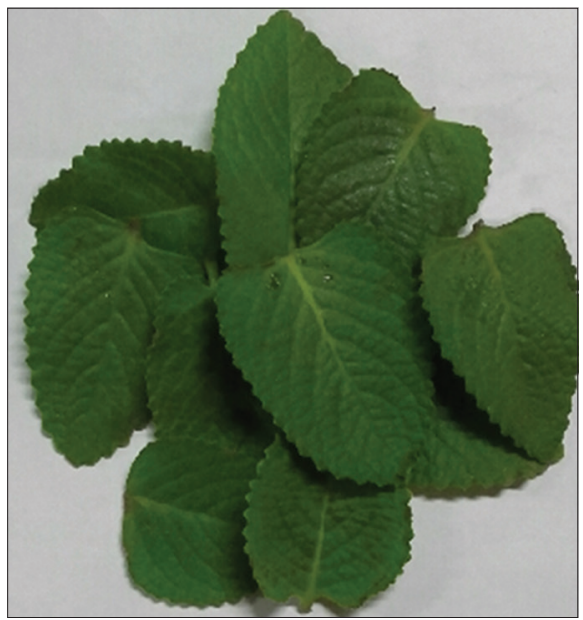

Fig. 1: Fresh leaves of Plectranthus amboinicus

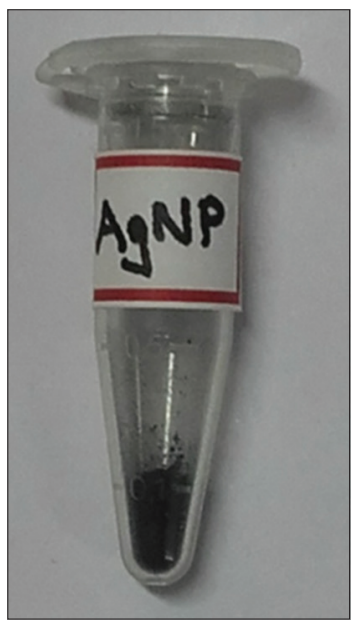

Fig. 2: Powder form of green mediated silver nanoparticles reaction mixture (Fig. 3). The occurrence of color change in the reaction mixture was due to the excitation of surface plasmon resonance in the AgNPs [16].

\section{UV-visible absorption spectroscopy}

The UV-visible spectra of $P$. amboinicus plant extract and colloidal solution of green mediated AgNPs showed strong peaks at $326 \mathrm{~nm}$ and $413 \mathrm{~nm}$, respectively (Figs. 4a and b). UV-visible absorption spectra of AgNPs showed an intense absorption peak due to its surface plasmon excitation which represents the collective excitation of a conduction electron in metal. A strong absorbance peaks observed between $400 \mathrm{~nm}$ and $420 \mathrm{~nm}$ indicated the presence of AgNPs [17].

\section{FTIR spectroscopy}

The FTIR spectra of plant extract and stabilized AgNPs are illustrated in Fig. 5a and b. FTIR spectrum of plant extract showed major absorbance bands at $3433.29 \mathrm{~cm}^{-1}, 3417.86 \mathrm{~cm}^{-1}, 2924.09 \mathrm{~cm}^{-1}, 2862.36 \mathrm{~cm}^{-1}$, $1616.35 \mathrm{~cm}^{-1}, 1411.89 \mathrm{~cm}^{-1}$, and $1064.71 \mathrm{~cm}^{-1}$ (Fig. 5a). The bands at $3433.29 \mathrm{~cm}^{-1}$ and $3417.86 \mathrm{~cm}^{-1}$ correspond to $\mathrm{O}-\mathrm{H}$ stretching vibrations indicating the presence of alcohol or phenol groups. The $\mathrm{C}-\mathrm{H}$ stretching at $2924.09 \mathrm{~cm}^{-1}$ and $2862.36 \mathrm{~cm}^{-1}$ corresponds to acyclic alkanes. The $\mathrm{C}=0$ stretching vibration at $1616.35 \mathrm{~cm}^{-1}$ indicates the presence of aromatic ketones or carboxyl groups. The FTIR spectrum bands at $1411.89 \mathrm{~cm}^{-1}$ and $1064.71 \mathrm{~cm}^{-1}$ are characteristics of aliphatic aldehydes and primary aliphatic amines, respectively. After reaction of a plant extract with $\mathrm{AgNO}_{3}$, the peaks are shifted to higher wavenumbers such as $3444.87 \mathrm{~cm}^{-1}, 2962.66 \mathrm{~cm}^{-1}, 1627.92 \mathrm{~cm}^{-1}, 1431.18 \mathrm{~cm}^{-1}$, and $1095.57 \mathrm{~cm}^{-1}(5 \mathrm{~b})$. This indicated the strong interaction of resultant nanoparticles with the functional groups of plant leaf extract. It is

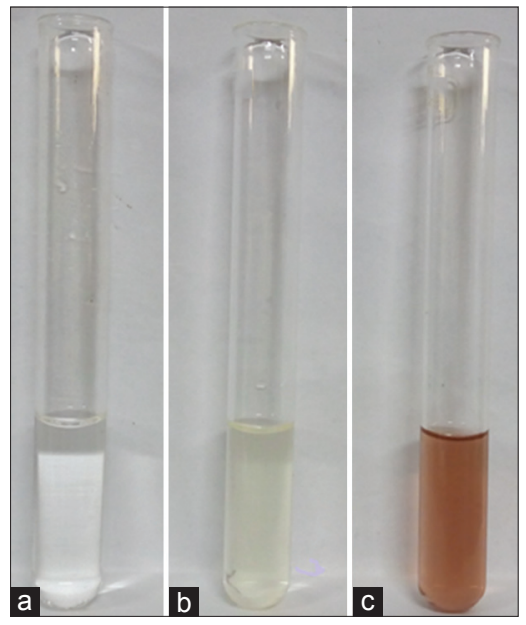

Fig. 3: Formation of silver nanoparticle colloidal solution. (a) $\mathrm{AgNO}_{3}$ solution, (b) plant leaf extract, and (c) silver nanoparticles colloid

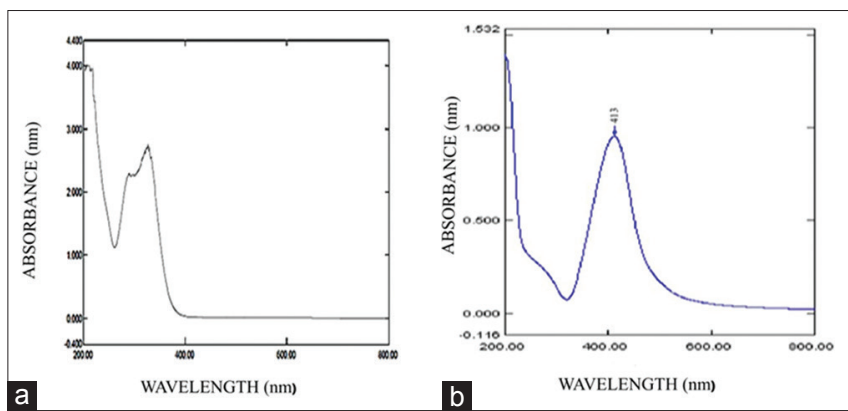

Fig. 4: Ultraviolet-visible absorption spectrum of Plectranthus amboinicus plant leaf extract (a) and leaf extract mediated silver nanoparticles (b) 

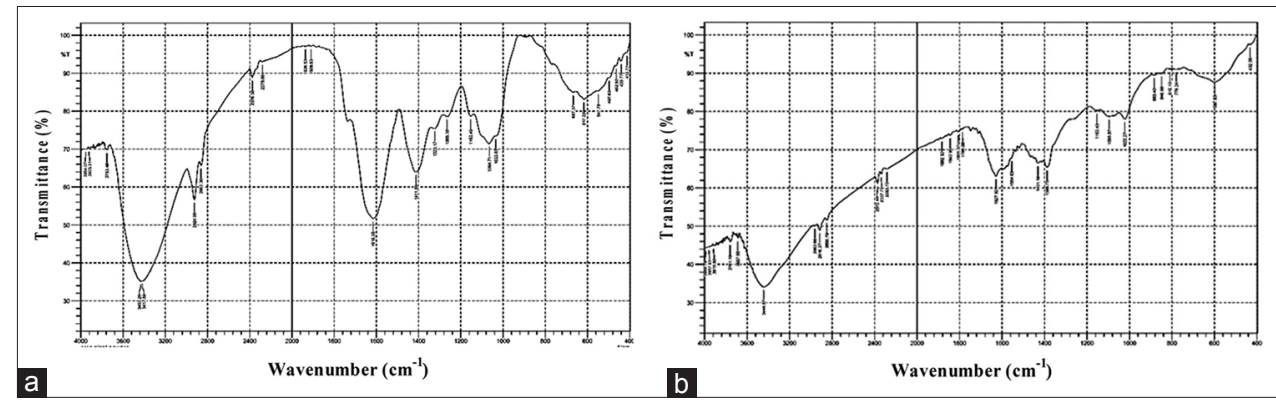

Fig. 5: Fourier transform infrared spectra of Plectranthus amboinicus plant leaf extract (a) and leaf extract mediated silver nanoparticles (b)

observed that functional group such as $\mathrm{O}-\mathrm{H}$ (hydroxyl), $\mathrm{C}=\mathrm{O}$ (carbonyl), $\mathrm{CHO}$ (aldehyde), and $\mathrm{NH}_{2}$ (amines) present in leaf extract was involved in the capping and stabilization of AgNPs that could prevent the particle aggregation [23].

\section{$X R D$}

Fig. 6 shows the XRD patterns of green mediated AgNPs. A number of Bragg's reflections with $2 \theta$ values of $37.86^{\circ}, 44.07^{\circ}, 64.31^{\circ}$, and $77.16^{\circ}$ corresponded to the (111), (200), (220), and (311) sets of lattice planes of face-centered cubic structure of metallic silver ions revealing that the synthesized AgNPs composed of pure crystalline silver [24]. The size of the green synthesized AgNPs was found to be $17.3 \mathrm{~nm}$. In addition, unassigned peaks appeared at $27.59^{\circ}, 32.00^{\circ}, 46.02^{\circ}, 54.58^{\circ}, 57.27^{\circ}$, and $67.22^{\circ}$. This may be due to the bioorganic compounds occurring on the surface of the AgNPs.

\section{SEM}

SEM image of $P$. amboinicus leaf extract-mediated, AgNPs were evenly shaped and spherical in nature (Fig. 7). From the given micrographs, it was observed that the synthesized nanoparticles were well dispersed. The aggregation of nanoparticles was attributed to the Van der Waals forces. Similar results were also reported for photosynthesized AgNPs $[24,25]$.

\section{$E D S$}

The elemental analysis of green mediated AgNPs was performed using EDS analysis recorded in the spot-profile mode. The resultant EDS spectra revealed strong signals in the silver region $(2.98 \mathrm{keV})$ and thus confirmed the formation of nanosilver in the prepared samples (Fig. 8). Throughout the scanning range of all EDS spectra, no other peaks hinting at impurity were detected. This indicated that the synthesized AgNPs were at levels of high purity. The appearance of additional peaks in the spectrum may be due to the components present in the P. amboinicus plant extract.

\section{Antibacterial studies of AgNPs}

Antibacterial activity of green mediated AgNPs and plant leaf extract was carried out qualitatively by determining the level of inhibition zone using agar well diffusion method, and the results are depicted in Table 2. The formation of an inhibition zone clearly indicates the mechanism of the biocidal action of nanoparticles. The examined plant extract of P. amboinicus and green synthesized AgNPs showed varying degrees of antibacterial activities against the selected pathogens. The pathogens susceptible to the antibacterial property of nanoparticles exhibited larger inhibitory zones. The antibacterial activity of $P$. amboinicus mediated AgNPs against tested pathogens showed a maximum zone of inhibition $(22.00 \pm 1.00 \mathrm{~mm})$ against Pseudomonas aeruginosa whereas minimum inhibitory zone of about $11.66 \pm 1.52 \mathrm{~mm}$ was observed against Enterobacter sp. Similar results had been previously reported [26]. P. amboinicus mediated AgNPs showed a greater antibacterial effect toward all the tested pathogenic strains when compared to plant extract. The size of the inhibition zone increased significantly with

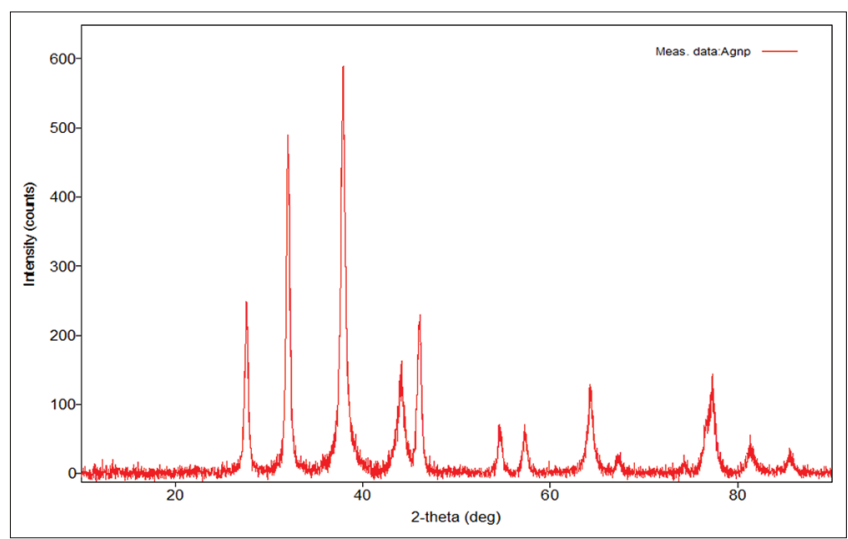

Fig. 6: X-ray diffraction spectrum of Plectranthus amboinicus leaf extract mediated silver nanoparticles

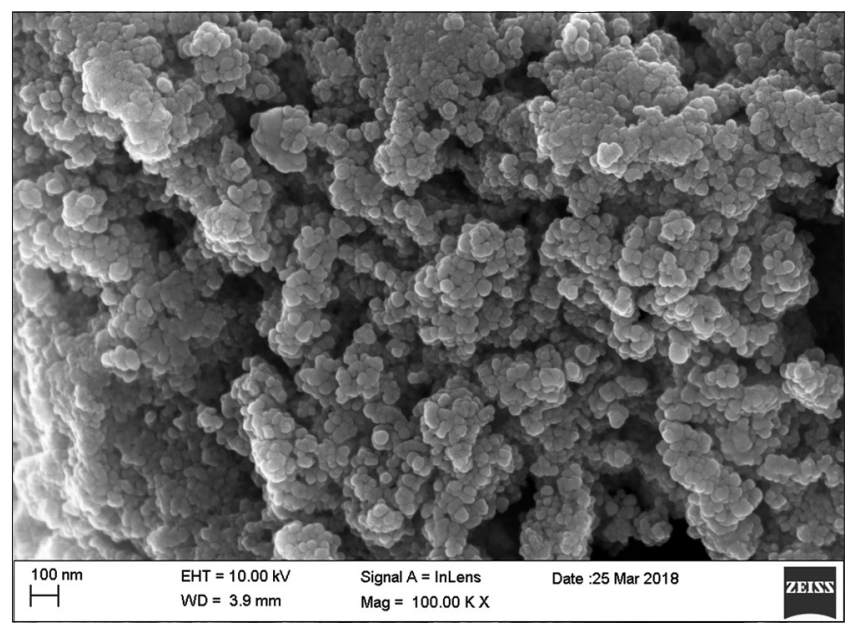

Fig. 7: Scanning electron micrograph of Plectranthus amboinicus plant leaf mediated silver nanoparticles

Table 2: Zone of inhibition ( $\mathrm{mm}$ ) of Plectranthus amboinicus leaf extract and AgNPs against selected UTI pathogens

\begin{tabular}{lll}
\hline $\begin{array}{l}\text { Name of the bacterial } \\
\text { pathogens }\end{array}$ & $\begin{array}{l}\text { Zone of inhibition }(\mathbf{m m}) \\
\text { (Mean } \pm \text { SD) }\end{array}$ & \\
\cline { 2 - 3 } & $\begin{array}{l}\text { Plant } \\
\text { extract }\end{array}$ & AgNPs \\
& $7.33 \pm 0.33$ & $22.00 \pm 1.00$ \\
\hline $\begin{array}{l}\text { Pseudomonas aeruginosa (G) } \\
\text { Enterobacter sp. (G-) }\end{array}$ & $6.00 \pm 0.00$ & $11.66 \pm 1.52$ \\
Klebsiella pneumoniae (G-) & $7.00 \pm 0.00$ & $14.00 \pm 1.00$ \\
Escherichia coli $(\mathrm{G}-)$ & $7.66 \pm 0.57$ & $13.00 \pm 1.00$ \\
\hline
\end{tabular}

AgNPs: Silver nanoparticles, G-: Gram-negative. UTI: Urinary tract infection 
decreasing size of the nanoparticles [27]. It is reasonable to state that the binding of smaller nanoparticles with the larger surface area to the bacteria cell wall will exhibit a greater bactericidal effect than the larger nanoparticles [28].

Determination of MIC and MBC of P. amboinicus mediated AgNPs The MIC of $P$. amboinicus mediated AgNPs against selected human UTI pathogenic bacteria is shown in Fig. 9. The broth dilution method revealed that the MIC of AgNPs was found to be $700 \mu \mathrm{g} / \mathrm{ml}$ for Klebsiella pneumoniae, $900 \mu \mathrm{g} / \mathrm{ml}$ for Enterobactersp., $400 \mu \mathrm{g} / \mathrm{ml}$ for P. aeruginosa, and $800 \mu \mathrm{g} / \mathrm{ml}$ for Escherichia coli. Increasing concentration of AgNPs substantially inhibited the growth of all bacterial strains in dose-dependent manner. The decrease in optical density is possibly associated with the cell envelope deformation occurring at the point of cell division. In the present experiment, optical density almost reached zero which reasons that there were no more bacteria present in the culture.

From the recorded data of $\mathrm{MBC}$, the bacterial growth gradually decreased as the concentration of nanoparticles increased due to the bactericidal property of green AgNPs. It was observed that the concentration of green synthesized AgNPs was ranged between $400 \mu \mathrm{g} / \mathrm{ml}$ and $900 \mu \mathrm{g} / \mathrm{ml}$. Based on the observed data, MIC and MBC values against
P. aeruginosa exhibited the highest susceptibility at a concentration of $400 \mu \mathrm{g} / \mathrm{ml}$ than the other tested strains. Table 3 summarizes the twoway ANOVA test which represents the bactericidal effect exhibited by green synthesized AgNPs and plant leaf extract on UTI pathogens. The variance due to bacterial pathogens were statistically significant $(\mathrm{F}=13.82 ; \mathrm{p}<0.05)$.

AgNPs have the ability to anchor to the bacteria cell wall, due to its larger surface area, subsequently penetrate it and thereby cause structural changes in the cell membrane like disrupting the permeability of the cell membrane which would lead to the leakage of intracellular components, thus killing the bacterial cells [29]. There is a formation of "pits" on the cell surface, and there is an accumulation of the nanoparticles on the cell surface [30]. The formation of free radicals by the AgNPs may be considered to be another mechanism by which the cells die. AgNPs induce the formation of reactive oxygen species in several bacteria which are responsible for inducing genetic variability, promoting cell death, and possibly regulating biofilm development [31]. Silver atoms form stable bonds with the thiol groups $(-\mathrm{SH})$ of enzymes involved in transmembrane energy generation and ion transport, thus deactivating them [32]. It was also proposed that silver ions enter the cell, intercalate between the purine and pyrimidine base pairs and disturbs the hydrogen bonding

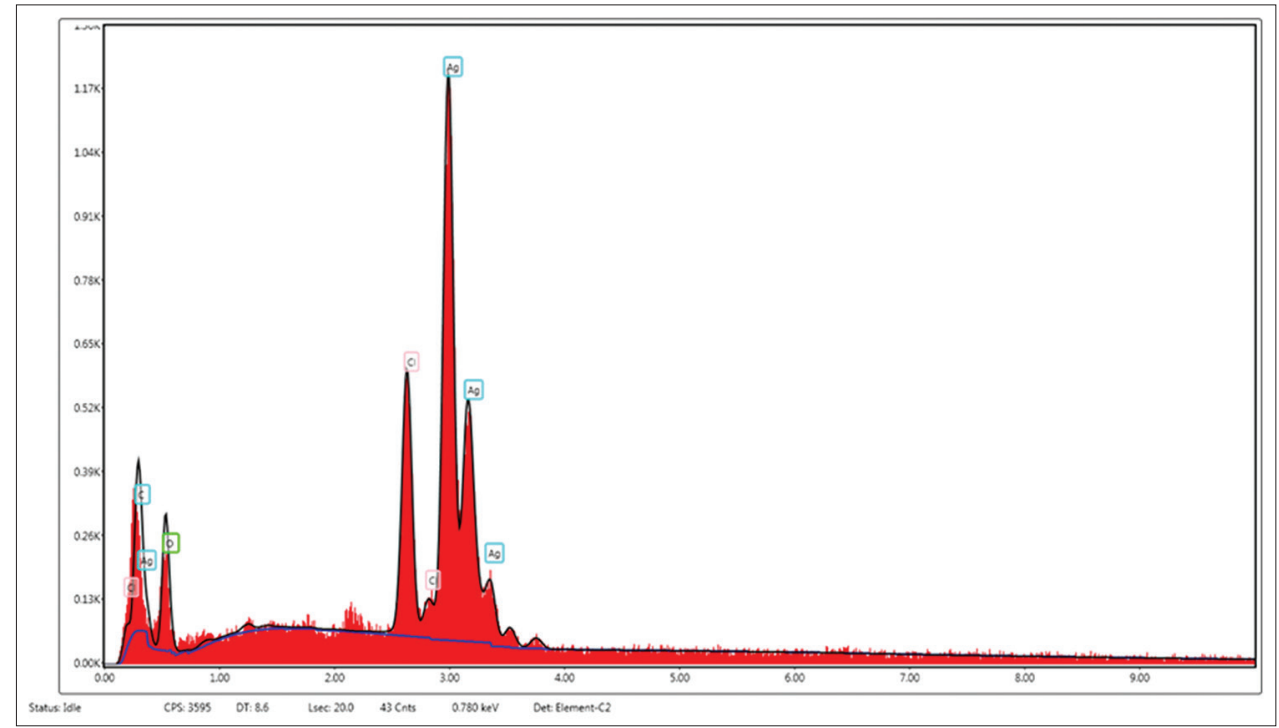

Fig. 8: Energy dispersive spectroscopy of Plectranthus amboinicus leaf extract-mediated silver nanoparticles
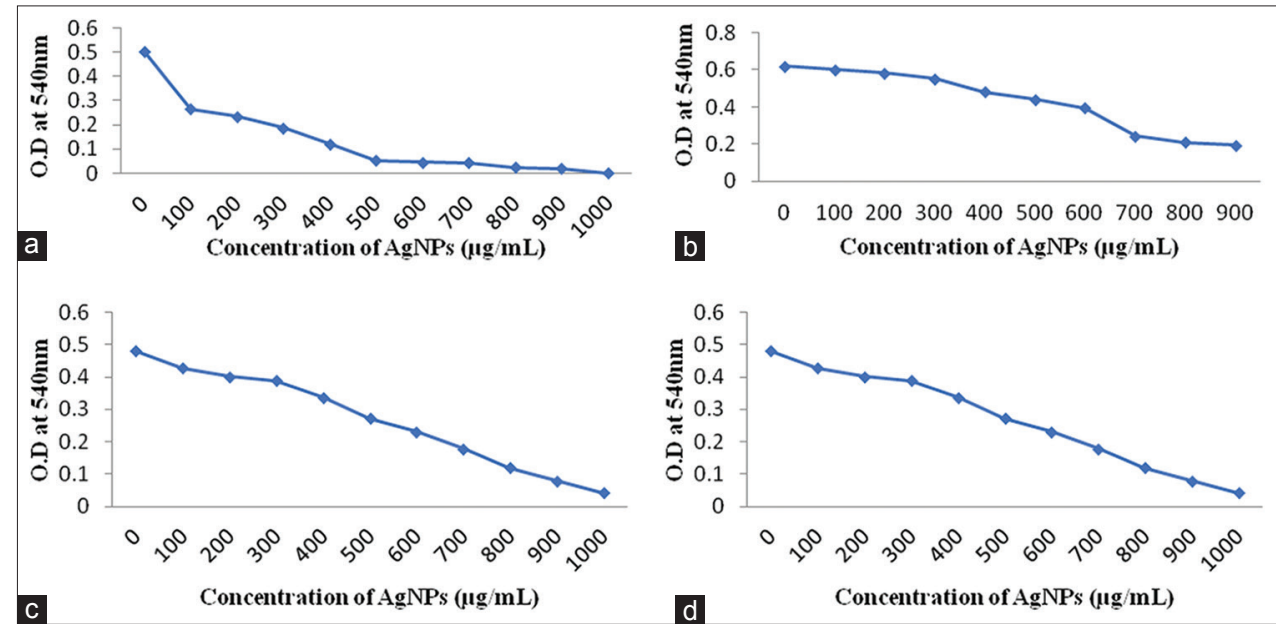

Fig. 9: Determination of minimum inhibitory concentration of green mediated silver nanoparticles against (a) Plectranthus amboinicus, (b) Enterobacter sp., (c) Escherichia coli, and (d) Klebsiella pneumonia 
Table 3: Two-way analysis of antibacterial activity of Plectranthus amboinicus leaf extract and AgNPs

\begin{tabular}{|c|c|c|c|c|c|}
\hline Source of variation & Sum of square & Factor $\mathrm{df}$ & Mean of square & F value & p value \\
\hline Variance due to bacterial pathogens & 37.62724 & 3 & 12.54241 & 1.299106 & $>0.05^{*}$ \\
\hline Variance due to AgNPs and plant extract & 133.4161 & 1 & 133.4161 & 13.81885 & $<0.05^{*}$ \\
\hline Error & 28.96394 & 3 & 9.654646 & & \\
\hline Total & 200.0073 & 7 & & & \\
\hline
\end{tabular}

${ }^{*} \mathrm{p}<0.05$ is statistically significant. AgNPs: Silver nanoparticles

Table 4: Assessment of activity index and fold area increase generated by Plectranthus amboinicus leaf extract and AgNPs against selected UTI pathogens

\begin{tabular}{llll}
\hline Name of the bacterial pathogens & Zone of difference $(\mathbf{m m}) \mathbf{( b - a )}$ & Activity index $(\mathbf{b} / \mathbf{a})$ & Fold $\mathbf{a r e a}$ increase $\left(\mathbf{b}^{2}-\mathbf{a}^{2} / \mathbf{a}^{2}\right)$ \\
\hline Pseudomonas aeruginosa $(\mathrm{G}-)$ & $14.67 \pm 0.67$ & $3.00 \pm 0.00$ & $8.01 \pm 0.01$ \\
Enterobacter sp. (G-) & $5.66 \pm 1.52$ & $1.94 \pm 0.26$ & $2.82 \pm 0.99$ \\
Klebsiella pneumoniae (G-) & $7.00 \pm 1.00$ & $2.00 \pm 0.14$ & $3.01 \pm 0.57$ \\
Escherichia coli $\left(\mathrm{G}^{-}\right)$ & $5.34 \pm 0.43$ & $1.70 \pm 0.01$ & $1.88 \pm 0.01$ \\
\hline
\end{tabular}

a: Zone of inhibition for the leaf extract, b: Zone of inhibition for the AgNPs. AgNPs: Silver nanoparticles, UTI: Urinary tract infection

between the DNA strands thus denaturing them. The interaction of the AgNPs with the sulfur and phosphorus of the DNA can lead to problems in DNA replication of the bacteria and thus terminate the microbial growth [33].

\section{Assessment of AI and fold area increase}

The assessment of AI and fold area increase between the P. amboinicus leaf extract and AgNPs against selected UTI pathogens was given in Table 4. It is revealed that the calculated AI of AgNPs was $>1 \quad(\mathrm{AI}>1)$, it means that all the bacterial strains used in the present study showed strong inhibitory actions. The maximum AI value was obtained for P. aeruginosa $(3.00 \pm 0.00)$ using AgNPs. The interactions of AgNPs with bacteria are dependent on the size and surface area of the nanoparticles [28]. The smaller AgNPs have more bactericidal activity than the AgNPs which possess a larger surface area.

Among the tested, UTI pathogens $P$. aeruginosa exhibited the highest increase in fold area $(8.01 \pm 0.01)$ followed by $K$. pneumoniae (3.01 \pm 0.57$)$ using with $P$. amboinicus mediated AgNPs. The mechanism of the bactericidal effect of Ag NPs can be attributed to the fact that they possibly attach to the surface of the cell membrane disturbing permeability and respiration functions of the cell [34].

\section{CONCLUSION}

Nanotechnology has paved the way to combat the challenges of multidrug resistance due to their unique physiochemical properties. Plant extracts and plant-derived compounds are likely to produce a valuable source of new medicinal agents for therapeutic use. P. amboinicus leaf extract-mediated AgNPs showed varying degrees of antibacterial property against the selected UTI pathogens. From the present study, it is concluded that the P. amboinicus leaf extractmediated AgNPs could be used as an effective antibacterial agent for the management of UTIs.

\section{ACKNOWLEDGMENT}

The authors are grateful to the management of PSG College of Arts and Science, Coimbatore, for their encouragement and their provision of facilities for this work.

\section{AUTHORS' CONTRIBUTIONS}

Author 1 has conducted the experiment and the experiment was planned and guided by Author 2 .

\section{CONFLICTS OF INTEREST}

The authors declared that there are no conflicts of interest regarding the publication of this article.

\section{REFERENCES}

1. Hema TA, Shiny M, Parvathy J. Antimicrobial activity of leaves of Azima tetracantha agaisnt clinical pathogens. Int J Pharm Pharm Sci 2012;4:317-9

2. Nickel JC. Management of urinary tract infections: Historical perspective and current strategies: Part 1-Before antibiotics. J Urol 2005;174:1502.

3. Stamm WE, Norrby SR. Urinary tract infections: Disease panorama and challenges. J Infect Dis 2001;183 Suppl 1:S1-4.

4. Gupta K, Hooton TM, Naber KG, Wullt B, Colgan R, Miller LG. International clinical practice guidelines for the treatment of acute uncomplicated cystitis and pyelonephritis in women: A 2010 update by the infectious diseases society of America and the European society for microbiology and infectious diseases. Clin Infect Dis 2011;5:103-20.

5. Sanchez GV, Master RN, Bordon J. Trimethoprim-sulfamethoxazole may no longer be acceptable for the treatment of acute uncomplicated cystitis in the United States. Clin Infect Dis 2011;53:316-7.

6. Morones JR, Elechiguerra JL, Camacho A, Holt K, Kouri JB, Yamacan MJ. The bactericidal effect of AgNPs. Nanotechnol 2005;16:2346-53.

7. Prema P, Thangapandiyan S. In-vitro antibacterial activity of gold nanoparticles capped with polysaccharide stabilizing agents. Int $\mathrm{J}$ Pharm Pharm Sci 2013;5:310-4.

8. Kora AJ, Rastogi L. Enhancement of antibacterial activity of capped AgNPs in combination with antibiotics, on model gram-negative and gram-positive bacteria. Bioinorg Chem Appl 2013;2013:1-7.

9. Raffi M, Hussain F, Bhatti TM, Akhter JI, Hameed A, Hasan MM. Antibacterial characterization of silver nanoparticles against E. coli ATCC-15224. J Mater Sci Technol 2008;24:192-6.

10. Udapudi B, Naik P, Savadatti ST, Sharma R, Balgi S. Synthesis and characterization of AgNPs. Biol Sci 2012;2:10-4.

11. Pattanayak M, Nayak PL. Green synthesis and characterization of zero valent iron nanoparticles from the leaf extract of Azadirachta indica (Neem). World J Nanosci Technol 2013;2:6-9.

12. Roshan P, Naveen M, Manjul PS, Gulzar A, Anita S, Sudarshan S. Plectranthus amboinicus (Lour) spreng: An overview. Pharm Res 2010;4:1-15

13. Singh G, Singh OP, Prasad YR, Lamposona MP, Catalan C. Studies on essential oils. Part 33: Chemical and insecticidal investigations on leaf oil of Coleus amboinicus (Lour). Flavour Fragr J 2002;17:440-2.

14. Murthy PS, Ramalakshmi K, Srinivas P. Fungitoxic activity of Indian borage (Plectranthus amboinicus) volatiles. Food Chem 2009;114:1014-8.

15. Senthilkumar A, Venkatesalu V. Chemical composition and larvicidal activity of the essential oil of Plectranthus amboinicus (Lour.) spreng against Anopheles stephensi: A malarial vector mosquito. Parasitol Res 2010;107:1275-8

16. Abirami S, Nishanthini K, Poonkothai M. Antimicrobial activity and phytochemical screening of the leaf extracts of Eucalyptus globulus. Int J Curr Pharm Res 2017;9:85-9.

17. Nirjanta DP, Dheeban S, Femina W, Paramasivam T. Antimicrobial efficacy of green synthesized AgNPs from the medicinal plant Plectranthus amboinicus. Int J Pharm Sci Rev Res 2012;12:164-8

18. Trease GE, Evans WC. Textbook of Pharmacognosy. 14 $4^{\text {th }}$ ed. Balliere Tindal, London: W. B. Saunders Company Ltd.; 1989. 
19. Wang ZL. Characterization of nanophase materials. Part Part Syst Charact 2001; 18:142-65.

20. Bauer AW, Kirby WM, Sherris JC, Turck M. Antibiotic susceptibility testing by a standardized single disk method. Am J Clin Pathol 1966;45:493-6.

21. Ruparelia JP, Chatterjee AK, Duttagupta SP, Mukherji S. Strain specificity in antimicrobial activity of silver and copper nanoparticles. Acta Biomater 2008;4:707-16

22. Wang C, Liu LL, Zhang AT, Xie P, Lu JJ, Zou XT. Antibacterial effect of zinc oxide nanoparticles on Escherichia coli K88. Afr J Biotechnol 2012;11:10248-54

23. Zheng Y, Wang Z, Peng F, Fu L. Biosynthesis of AgNPs by Plectranthus amboinicus leaf extract and their catalytic activity towards methylene blue degradation. Rev Mex Ing Quim 2017;16:41-5.

24. Thangapandiyan S, Prema P. Chemically fabricated AgNPs enhances the activity of antibiotics against selected human pathogens. Int $\mathrm{J}$ Pharm Sci Res 2012;3:1415-22.

25. Sathishkumar G, Gobinath C, Kapagam K, Hemamalini V, Premkumar K, Sivaramakrishnan S. Phyto-synthesis of AgNPs using Morinda citrifolia L. and its inhibitory activity against human pathogens. Colloid Surf B 2012;95:235-40.

26. Samuel JI, Ravikumar S, Manikandan N. Antibacterial potential of AgNPs against isolated urinary tract infections bacterial pathogens. Appl Nanosci 2011;1:231-26.
27. Padmavathy N, Vijayaraghavan R. Enhanced bioactivity of $\mathrm{znO}$ nanoparticles-an antimicrobial study. Sci Technol Adv Mater 2008;9:035004.

28. Panacek A, Kvítek L, Prucek R, Kolar M, Vecerova R, Pizúrova N, et al. Silver colloid nanoparticles: Synthesis, characterization, and their antibacterial activity. J Phys Chem B 2006;110:16248-53.

29. Qi L, Xu Z, Tiang X, Hu C, Zou X. Preparation and antibacterial activity of chitosan nanoparticles. Carbohydr Res 2004;339:2693-700.

30. Sondi I, Salopek-Sondi B. AgNPs as antimicrobial agent: A case study on $E$. coli as a model for gram-negative bacteria. J Colloid Interface Sci 2004;275:177-82.

31. Gurunathan S, Han JW, Kwon DN, Kim JH. Enhanced antibacterial and anti-biofilm activities of silver nanoparticles against gram-negative and gram-positive bacteria. Nanoscale Res Lett 2014;9:373.

32. Ahmed S, Ahmad M, Swami BL, Ikram S. A review on plants extract mediated synthesis of AgNPs for antimicrobial applications: A green expertise. J Adv Res 2016;7:17-28.

33. Prabhu S, Poulose EK. AgNPs: Mechanism of antimicrobial action, synthesis, medical applications, and toxicity effects. Int Nano Lett 2012;2:32

34. Prema P, Thangapandiyan S, Immanuel G. CMC stabilized nano silver synthesis, characterization and its antibacterial and synergistic effect with broad spectrum antibiotics. Carbohydr Polym 2017;158:141-8. 